\title{
Collaborative spaces: organizational, spatial and relational crossover for new ways of working
}

\author{
Alessandra Migliore \\ alessandra.migliore@polimi.it \\ Department of Architecture, Built Environment and Construction Engineering, \\ Politecnico di Milano, Italy Politecnico di Milano, \\ Chiara Tagliaro \\ chiara.tagliaro@polimi.it \\ Department of Architecture, Built Environment and Construction Engineering, \\ Politecnico di Milano, Italy
}

\section{Introduction}

The world counts more than 14 thousand coworking spaces and 35 thousand flexible workspaces whose primary function is to offer dedicated spaces for collaborative activities in order to trigger higher creative performances with new ways of working (Leesman, 2015). Why are collaborative spaces so relevant in contemporary society? Collaborative spaces (CS) are defined as places whose codes, atmosphere, and times and values of use favour horizontal interactions (De Vaujany et al., 2018). Among these spaces, mainly pertaining to the work realm, we recognize collaborative workplaces in corporate offices, coworking spaces, hacker- and maker-spaces, fablabs and also multifunctional spaces inside universities (Botsman \& Rogers, 2011; Gandini, 2015; Temple, 2019). Collaborative workplaces are not only those areas specifically designed for planned collaboration, such as team and meeting rooms, but also the office locations where more casual collaboration and impromptu interactions happen among workers, such as service and amenityrelated spaces, including printing and copy areas, breakout areas and so on (Hua et al., 2011). Collaborative spaces are based on the possible sharing of knowledge, either planned or unplanned (Moriset, 2014; Mitev et al., 2018), that takes place thanks to the flexibility of their forms and functions, to users' inclusion and to their spatial and managerial fragmentation (Friedman, 2014; Schmidt, 2019).

However, a clear taxonomy of CS and their impacts on users are not well-established due to (i) the constantly evolving scenario of workplaces and work practices, mainly determined by the increased availability of technologies, and (ii) the extensive role that knowledge sharing plays as a key production factor in modern cities and economic systems. While rigid separation of places to live, work, have fun or produce is blurring, many places are becoming 'hybrid' through a process that has been even accelerated by recent emergencies - as the pandemic we are currently facing worldwide. Aided by technological and digital innovation, nearly any place can accommodate temporary and multiple functions, including collaborative practices. Literature suggests defining CS as "fourth places" (Morrison, 2018), because they integrate some of the characteristics of three categories of place: the place for living (first place); the place for work (second place); and the place for relationships and leisure time or "third place" (Oldenburg \& Brisset, 1989; Oldenburg, 1982). By implying the hybridisation of these three levels, CS enable practices and social encounters that are not found elsewhere, especially not at home nor at other workplaces (Yang et al., 2018; 
Oldenburg 1989; Moriset, 2013; Simões Aelbrecht, 2016). Thus, CS can take place in different environments and can affect a variety of users.

Literature on CS is scattered across multiple disciplines. It includes conceptual and empirical studies mainly within social sciences (e.g. Spreitzer, 2017), architecture (e.g. Simões Aelbrecht, 2016), real estate management (e.g. Yang, 2019), facility management (e.g. Weijs-Perrée, 2018), organization and management (e.g. De Vaujany, 2018) and human resource management (e.g. Boutellier, 2008). However, most studies adopt a single-discipline perspective, while a more transversal and inter-disciplinary stance is desirable to understand the interplay of CS in different environments and their impact on users. It is necessary to systematise the existing literature through a comprehensive taxonomy of collaborative spaces (Ciaramella et al., 2018). Therefore, this research proposes a wide-ranging analysis that considers the multiple dimensions of CS based on a cross-disciplinary approach. The aim is to understand which dimensions of collaborative spaces have an impact on their users, and what outcomes can be expected i.e. on innovation, entrepreneurship, creativity, and value generation (Colpaert, et al. 2014; Corvo \& Pastore, 2018; Putnam, 2000).

\section{Framework for a multidisciplinary investigation}

A thorough literature review allowed to acknowledge, on one hand the spatial, organizational and relational dimensions - according to the spatial triad of Lefebvre (1991) - that can impact CS' users and, on the other hand, users' expected outcomes.

The spatial dimension of CS can have both positive and negative impacts on workers. Orel and Almeida (2019) recognize furniture's flexibility, brightness of workspace, temperature range, air quality, and the presence of greenery as supportive factors to trigger relationships and wellbeing among coworkers. The same features can facilitate cross-fertilization and lateral thinking, which are important factors for creativity and innovation (Dul, Ceylan and Jaspers, 2011). Multispace layout can both favour or hamper face-to-face interactions (Boutellier et al., 2008; Stryker et al. 2012; Weijs-Perrée et al., 2018; Von Krogh and Geilinger, 2014). However, spatial design alone does not suffice to trigger positive relational outcomes but needs to blend well with other factors, such as organizational culture and organization of work activities (Becker, 2007; Von Krogh and Geilinger, 2014). Among the organizational dimensions of CS, Spreitzer et al. (2017) state the relevance of flexibility in terms of relationships, time and location. Outcomes of these varied levels of flexibility include (i) 'geographic proximity' between workers that refers to the physical vicinity of two entities to each other, and (ii) 'perceived proximity' (Wilson et al., 2008) that is the inherent closeness of two entities, despite their physical distance. This unique combination of both types of proximity with a values-based orientation distinguishes collaborative spaces from traditional office environments (Yang et al., 2019; Kojo and Nenonen, 2014).

Among the relational dimensions, CS can be defined as 'serendipity machines' that favour impromptu interactions among their users (Olma, 2013) while enhancing social capital (Waxman, 2004), supporting innovation and entrepreneurship processes (Boutellier et al., 2008; Coradi et al., 2015; Stryker et al., 2012) or spreading tacit knowledge (Polanyi, 2009). Moreover, Wasserman and Frenkel (2015), following Bourdieu's (1984) discourse, report the relevance of CS' distinctive factor of peer-interactions to redefine and transform stereotyped performative habitus.

This analysis shows that the existing knowledge on CS can be systematised into an interpretive framework, consisting of two main components. On one hand, spatial, organizational and relational dimensions can be recognized as determinants of CS' impacts on users. On the other hand, users can expect multiple outcomes from the fruition of CS. Further studies on the relations between these two main components will allow to define a taxonomy of CS. 


\section{Conclusions and future development of the research}

This literature review built a complete interpretive scheme of collaborative spaces (CS), that acknowledges specific dimensions of CS and their expected outcomes on users. The complexity of CS' multiple features, their latent hybridisation, and the multiplicity of potential outcomes were captured by embracing a cross-disciplinary perspective. These findings constitute a fundamental basis to develop a more elaborated taxonomy of CS, which will be useful to investigate them in future systematic studies. In particular, new research areas can be envisioned, among which: how the recent pandemic is affecting CS dimensions and outcomes; what input variables are specifically included in each dimensions and determine specific outcomes; and what categories of CS users can be identified.

This first exploration might be of interest not only for researchers, but also for executives, human resources managers, and managers in charge of corporate social responsibility who are increasingly called to implement inclusive, innovative and creative work practices to boost performances and job satisfaction of workers and other workplace users. Also, these results can support policymaking to diffuse CS throughout urbanized and peripheral environments, as well as can support the evolution of university campuses into more engaging environments for academic personnel, students, and the society at large.

\section{References}

[1] Botsman, R. \& Rogers, R. (2011). What's Mine is Yours: The Rise of Collaborative Consumption. New York, NY: Harper Business

[2] Bourdieu, P. (1984). Distinction: A social critique of the judgement of taste. Cambridge, MA: Harvard University Press.

[3] Boutellier, R., Ullman, F., Schreiber, J., \& Naef, R. (2008). Impact of office layout on communication in a science-driven business. R\&D Management, 38(4), 372-391.

[4] Ciaramella A., Rossi-Lamastra C., Rovelli P., Tagliaro C. (2018), Who talks about collaborative spaces, how, and why, Journal of Experimental Innovation, 2018; 2(1): 3-7

[5] Colpaert, A., Sutherland, S. \& Elliott, L., (2014). Forget the Workplace... for Now, Publisher: Jones Lang LaSalle.

[6] Coradi, A., Heinzen, M. and Boutellier, R. (2015a), "Designing workspaces for cross-functional knowledge-sharing in R\&D: The 'co-location pilot' of novartis", Journal of Knowledge Management, Vol. 19 No. 2, pp. 236-256.

[7] Corvo L. Pastore L. (2018), La costellazione del valore: approcci collaborativi oltre Porter, Paper presentato in occasione del XII Colloquio Scientifico sull'impresa sociale, 25-25 maggio 2018, Dipartimento di Sociologia e Ricerca Sociale, Università degli Studi di Trento, Iris network.

[8] De Vaujany, F.-X., Dandoy, A., Grandazzi, A., \& Faure, S. (2018). Experiencing a New Place as an Atmosphere: A Focus on Tours of Collaborative Spaces. Scandinavian Journal of Management.

[9] Dul, J., Ceylan, C., Jaspers, F. (2011). "Knowledge worker creativity and the role of the physical work environment". Human Resource Management, 50(6): 715-734.

[10] Friedman, G. (2014). Workers without employers: shadow corporations and the rise of the gig economy. Review of Keynesian Economics, 2(2). 
[11] Gandini, A. (2015). The rise of coworking spaces: a literature review. Ephemera: Theory \& Politics in Organization, Vol. 15, No. 1, pp.193-205.

[12] Golden T, Raghuram S. (2010). Teleworker knowledge sharing and the role of altered relational and technological interactions. J. Organ. Behav. 31:1061-85

[13] Hua, Y., Loftness, V., Heerwagen, J.H. and Powell, K.M. (2011), "Relationship between workplace spatial settings and occupant- perceived support for collaboration", Environment and Behavior, Vol. 43 No. 6, pp. 807-826.

[14] Kojo, I. and Nenonen, S. (2014), "User experience in an academic coworking place: the case of Aalto university's design factory", in Proceedings of the CIB Facilities Management Conference, Copenhagen, pp. 21-23.

[15] Lefebvre, H. (1974). The production of space (Ed. 1991.). Oxford: Blackwell.

[16] Leesman (2017), The Next 250K Report. Retrieved from: www.leesmanindex.com (accessed 17 March 2020).

[17] Mitev N., De Vaujany F., Laniray P., Bohas A., Fabbri J. (2018), Co-working spaces, collaborative practices and entrepreneurship, in "Collaboration in the Digital Age", edited by K. Riemer and S. Schellhammer, Springer Verlag.

[18] Moriset, B. (2014) Building New Places of the Creative Economy. The Rise of Coworking Spaces [online] https://halshs.archives-ouvertes.fr/halshs-00914075 (accessed $17 \mathrm{March}$ 2020).

[19] Morisson, A. (2018), A typology of places in the knowledge economy: towards the fourth place, International Symposiumon New Metropolitan Perspectives, Springer, Cham, pp. 444451.

[20] Oldenburg, R. \& Brissett, D. (1982). The third place. Qualitative sociology, 5(4), 265-284.

[21] Oldenburg, R. (1989). The great good place: Café, coffee shops, community centers, beauty parlors, general stores, bars, hangouts, and how they get you through the day. Vadnais Heights: Paragon House Publishers.

[22] Olma, Sebastian (2013). The Serendipity Machine. Stichting Society 3.0. Kindle Edition.

[23] Orel, M. and Alonso-Almeida, M.D.M. (2019), "The ambience of collaboration in coworking environments", Journal of Corporate Real Estate.

[24] Polanyi, M. (2009). The Tacit Dimension. Chicago: University of Chicago Press.

[25] Putnam, R.D. (2000) Bowling Alone: The Collapse and Revival of American Community, New York, NY: Simon and Schuster.

[26] Schmidt, S. (2019). In the making: Open Creative Labs as an emerging topic in economic geography? Geography Compass.

[27] Simões Aelbrecht, P. (2016). 'Fourth places': the contemporary public settings for informal social interaction among strangers, Journal of Urban Design, 21:1, 124-152.

[28] Spreitzer, G.M., Cameron, L. and Garrett, L., (2017). Alternative work arrangements: Two images of the new world of work. Annual Review of Organizational Psychology and Organizational Behavior, 4, pp.473-499. 
[29] Stryker, J. B., Santoro, M. D., \& Farris, G. F. (2012). Creating collaboration opportunity: Designing the physical workplace to promote high-tech team communication. IEEE Transactions on Engineering Management, 59(4), 609-620.

[30] Temple, P. (2019). University spaces: Creating cité and place. London Review of Education, 17 (2): $223-235$.

[31] Von Krogh G., Geilinger N. (2014) Knowledge creation in the eco-system: Research imperatives. European Management Journal 32, 155-163.

[32] Wasserman, V., Frenkel, M. (2015). "Spatial work in between glass ceilings and glass walls: Gender-class intersectionality and organizational aesthetics". Organization Studies, 36(11): $1485-1505$.

[33] Weijs-Perrée, M., Appel-Meulenbroek, R., Arentze, T., \& Romme, G. (2018). The influence of personal- and business centre characteristics on knowledge sharing types in business centres. Facilities.

[34] Wilson, J. M., Boyer O'Leary, M., Metiu, A., \& Jett, Q. R. (2008). Perceived Proximity in Virtual Work: Explaining the Paradox of Far-but-Close. Organization Studies, 29(7), 979-1002.

[35] Yang E., Bisson C., Eaton Sanborn B. (2019). Coworking space as a third-fourth place: changing models of a hybrid space in corporate real estate. Journal of Corporate Real Estate. ISSN: 1463-001X. 